\title{
Ophiomorpha irregulaire and associated trace fossils from the Upper Cretaceous of Patagonia, Argentina: Palaeogeographical and ethological significance
}

\author{
María I. LÓPEZ CABRERA ${ }^{1^{*}}$ \& Eduardo B. OLIVERO
}

\author{
${ }^{1}$ Laboratorio de Geología Andina, Centro Austral de Investigaciones Científicas, CADIC-CONICET, B. A. Houssay 200,9410 \\ Ushuaia, Tierra del Fuego, Argentina; emolivero@gmail.com \\ * Corresponding author
}

López Cabrera, M.I. \& Olivero, E.B. 2014. Ophiomorpha irregulaire and associated trace fossils from the Upper Cretaceous of Patagonia, Argentina: Palaeogeographical and ethological significance. [Ophiomorpha irregulaire y trazas fósiles asociadas del Cretácico Superior de Patagonia, Argentina: significados paleogeográfico y etológico]. Spanish Journal of Palaeontology, 29 (1), 33-44.

\begin{abstract}
There are two contrasting opinions on the stratigraphic and palaeogeographic distribution of the relatively rare trace fossil Ophiomorpha irregulaire: 1) the trace is mostly restricted to the Upper Cretaceous of the Western Interior Seaway, or 2) it has a post-Palaeozoic record and a worldwide geographic distribution. In this study we document the finding of $O$. irregulaire in Upper Cretaceous turbidites of the Alta Vista Formation, southern Patagonia, providing additional evidence on the morphology and composition of its pelletal masses, the ethology of its producer and the palaeogeographical and palaeoenvironmental distribution of the trace fossil. The burrow walls are lined with dark mud and their elongate, spiky pellets are formed by a sand core that is also lined with mud. The association with typical fodinichnia, such as Halopoa, Spirophyton, and Zoophycos and the common presence of $O$. irregulaire in sediments with abundant plant detritus, suggest that the producer was a deposit feeder. Crosscutting relationships and occurrences at several levels
\end{abstract}

RESUMEN

Existen dos opiniones contradictorias sobre la distribución estratigráfica y paleogeográfica de la relativamente rara traza fósil Ophiomorpha irregulaire: 1) la traza está restringida principalmente al Cretácico Superior del Mar Interior Occidental, o 2) tiene registro post-Paleozoico y una distribución geográfica mundial. En este estudio documentamos el hallazgo de $O$. irregulaire en turbiditas del Cretácico Superior de la Formación Alta Vista, al sur de la Patagonia, proporcionando evidencia adicional sobre la morfología y la composición de sus masas peletales, la etología de su productor y la distribución paleogeográfica y paleoambiental de la traza fósil. Las paredes de la madriguera están llenas de fango oscuro, y sus pellets espinosos y alargados están formados por un núcleo de arena que también está revestido por barro. La asociación con fodinichnia típicos, como Halopoa, Spirophyton y Zoophycos y la presencia frecuente de $O$. irregulaire en sedimentos con abundante detritus vegetal, sugieren que el productor era un detritívoro. 
within thick-bedded turbidites, suggest a relatively deep tier emplacement of the trace. The finding of the trace in the Southern Hemisphere supports its envisaged worldwide palaeogeographic distribution.

Keywords: Upper Cretaceous, southern Argentina, ichnology, Ophiomorpha irregulaire, slope deposits.
Las relaciones transversales y la presencia en varios niveles dentro de turbiditas potentes, sugieren un emplazamiento de la traza en un nivel relativamente profundo. El hallazgo de la traza en el Hemisferio Sur apoya su distribución paleogeográfica mundial prevista.

Palabras clave: Cretácico Superior, Sur de Argentina, icnología, Ophiomorpha irregulaire, depósitos de talud.

\section{INTRODUCTION}

The gallery systems of Ophiomorpha irregulaire Frey, Howard \& Pryor, 1978, form a particular meander maze configuration better appreciated in horizontal view. Apart from several Late Cretaceous outcrop localities in the type area of the Book Cliffs, central Utah, USA (Howard \& Frey, 1984; Bromley \& Ekdale, 1998) and the Atane Formation, West Greenland (Pedersen \& Bromley, 2006; Bromley \& Pedersen, 2008), the record of well-preserved specimens of this trace has been considered rare in the fossil record. Conversely, $O$. irregulaire has been commonly mentioned in well core studies of post-Palaeozoic strata (cf., Boyd et al., 2012); however, the spiky shape of the pelleted wall lining -which is generally used as the diagnostic criterion particularly in cross section views of core-based material, have been criticised as diagnostic feature of $O$. irregulaire (Bromley \& Pedersen, 2008). On this basis, these authors postulated that true $O$. irregulaire are stratigraphically and geographically restricted to the Late Cretaceous of the Western Interior area of North America and West Greenland.

Recent researches (McIlroy et al., 2009; Boyd et al., 2012), based on the study of the type material from central Utah, confirm that both the meander maze and the spiky pellets are important ichnotaxobases in classifying $O$. irregulaire. Furthermore, new advances using serial grinding techniques reveal details in the pelletal composition that indicate the validity of the pelletal morphology and composition as important taxobase at the ichnospecific level. On this basis, Boyd et al. (2012) conclude that $O$. irregulaire is a truly cosmopolitan trace fossil, widely distributed in post-Palaeozoic, shallow marine strata.

In this study we report a new locality of Ophiomorpha irregulaire in southern Patagonia, Argentina, containing well-preserved meander maze galleries. In addition, the burrow walls are lined with dark mud, and their elongate spiky pellets are formed by a sand core that is also lined with mud. The trace fossil was recorded mainly in classical turbidites and thick-bedded sandy turbidites, rich in plant detritus, of the Late Cretaceous Alta Vista Formation at Lago Argentino, Santa Cruz Province (Fig. 1). Thus, the aims of this study are to document the new austral record of $O$. irregulaire, which confirms a wider palaeogeographical distribution of the ichnospecies; to assess the taxonomic and ethological importance of its morphological features; and to analyse briefly the associated trace fossils and their palaeoenvironmental distribution in the Upper Cretaceous strata of Lago Argentino and southern Chile.

\section{MATERIAL AND METHODS}

\subsection{Studied material}

The material of Ophiomopha irregulaire was collected or studied in the field during the austral summer field seasons of 2008-2013. The studied material was recorded in classical turbidites and thick, lenticular turbidite sandstones of the Upper Cretaceous Alta Vista Formation cropping out at Arroyo Centinela, Lago Argentino, Santa Cruz Province, Argentina (Fig. 1). Additional material was studied in the field in lenticular, thick-bedded sandy turbidites of the Upper Cretaceous Tres Pasos Formation in southern Chile in loose sandstone slabs used for building material at Estancia Guido. The collected material is housed in the palaeontological collections of the Centro Austral de Investigaciones Científicas (CADIC-CONICET), Ushuaia, under the numbers CADIC PI 303 to 309.

\subsection{Stratigraphical and ichnological framework}

The Upper Cretaceous foreland marine deposits exposed between Lago Argentino (Santa Cruz Province, Argentina) and Ultima Esperanza (Magallanes Province, Chile) show complex stratigraphic architectures reflecting the initial filling of a deep-marine foredeep trough, which was progressively covered by shallowing and southern prograding strata, which represent a vertical succession of slope, shelfal, and deltaic deposits (Fig. 1). The Upper 


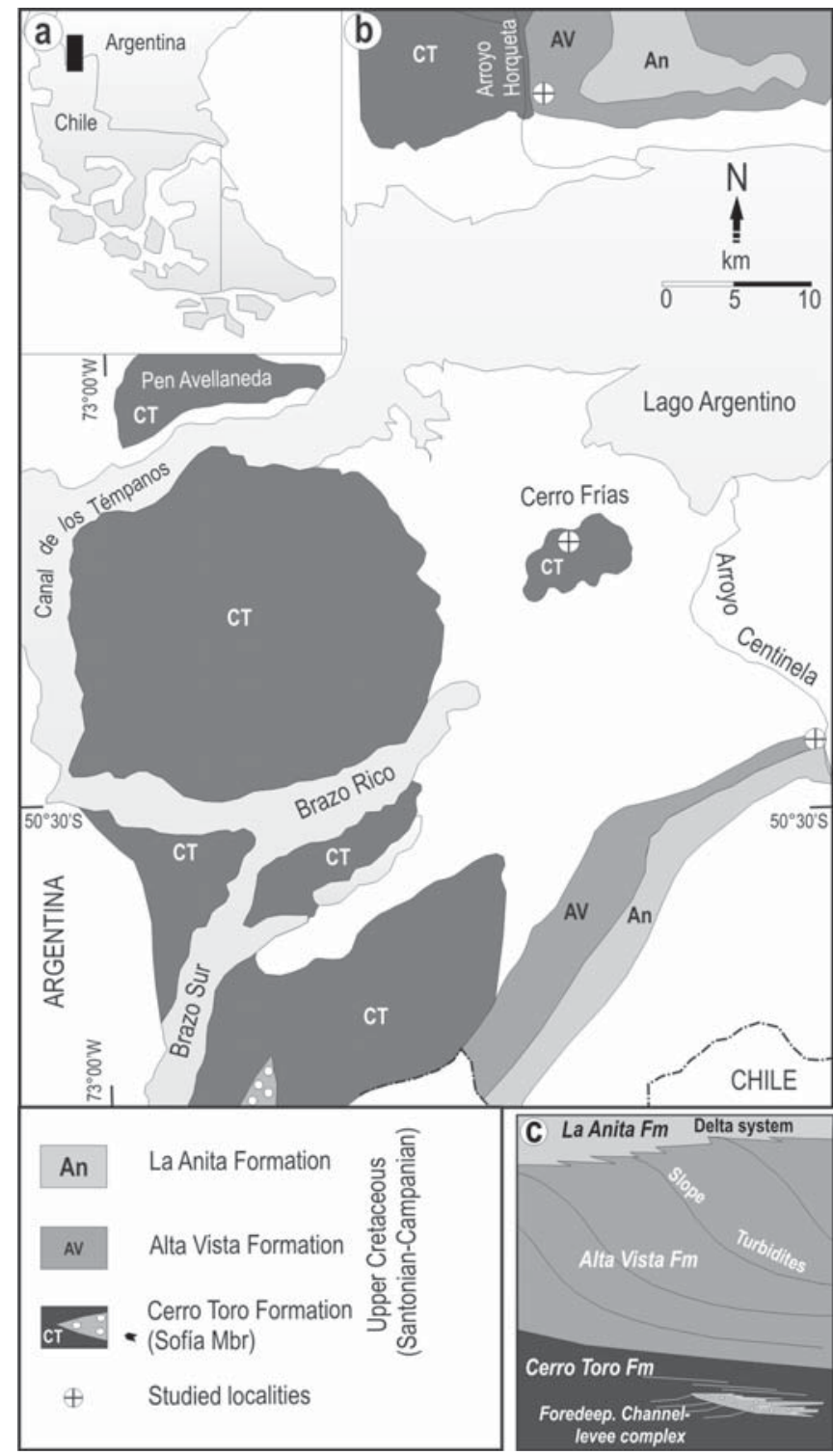

Figure 1. a) Location map. b) Geology of the studied area, modified after Arbe \& Hechem (1984) and Macellari et al. (1989). c) Palaeoenvironmental settings and architectural features of the studied Upper Cretaceous formations.

Cretaceous stratigraphical framework of the area, with different emphasis on lithostratigraphy and sequence stratigraphy, was successively developed mainly by Feruglio (1949), Katz (1963), Furque (1963), Riccardi (1983), Arbe \& Hechem (1984), and Macellari et al. (1989). In this paper, we follow with minor modifications the stratigraphical and palaeoenvironmental scheme of Arbe \& Hechem (1984) and Macellari et al. (1989). In this scheme, the deep-marine, basinal foredeep deposits of the Cerro Toro Formation are successively covered from north to south by slope deposits of the Alta Vista Formation, which in turn are covered by shelfal and deltaic deposits of the La Anita Formation (Fig. 1). In the adjacent Magallanes region of southern Chile, these units are equivalent to the basinal, deep-marine channellevee complex of the Cerro Toro Formation (Winn \& Dott, 1979; Hubbard et al., 2008), the slope deposits of the Tres Pasos Formation, and the deltaic deposits of the Dorotea Formation (Hubbard et al., 2010). To the north of Lago Argentino, the upper shallow marine Cretaceous deposits are transitionally replaced by fluvial strata, not shown in Figure 1 (see Macellari et al., 1989).

At the studied localities of Cerro Frías, Arroyo Horqueta, and Arroyo Centinela (Fig. 1), the Cerro Toro and Alta Vista strata show distinctive sedimentary facies and ichonological assemblages. At Cerro Frías, the Cerro Toro Formation (Fig. 2a) consists of thinbedded turbidites (Arbe \& Hechem, 1984), which bear a distinctive ichnoassemblage (Figs 2b-d, 2f) dominated by Scolicia strozzi (Savi \& Meneghini, 1850) and the graphoglyptids Desmograpton ichthyforme (Macsotay, 1967), Helminthorhaphe flexuosa Uchman, 1995 and Megagrapton submontanum (Azpeitia-Moros, 1933) (see Olivero \& López Cabrera, 2012). These thin-bedded turbidites were originally interpreted as distal fan-fringe deposits (Arbe \& Hechem, 1984) and later reinterpreted as probable interchannel or distal levees deposits (Olivero \& López Cabrera, 2012). The latter interpretation is more consistent with the occurrence of these strata in an upcurrent direction respect to the impressive channel and levee deposits of the coetaneous Cerro Toro Formation in southern Chile (see Hubbard et al., 2008).

At Arroyo Centinela, the Alta Vista Formation (Fig. 2e) consists of thick, lenticular sandstone beds associated with classical turbidites and mudstones (Arbe \& Hechem, 1984; Macellari et al., 1989), preserving abundant carbonized plant material. These beds bear a distinctive ichnoassemblage (Figs 2g-h, 3a-b) consisting of Ophiomorpha irregulaire Frey, Howard \& Pryor (1978) and Zoophycos isp. in the thick sandstones, and Ophiomorpha irregulaire, Halopoa annulata (Ksiażkiewicz, 1977) and Spirophyton isp. in the classical turbidites. Tasselia ordamensis de Heinzelin, 1964 is relatively common in the associated mudstones (Olivero \& López Cabrera, 2010, 2012).

At Arroyo Horqueta, the Alta Vista Formation (Fig. 3c) consists of lenticular, thick-bedded sandstones, which bear at its base abundant specimens of $O$. annulata (Książkiewicz, 1977) and O. rudis (Książkiewicz, 1977) (Fig. 3d).

\section{SYSTEMATIC ICHNOLOGY}

Ichnugenus Ophiomorpha Lundgren, 1891

Ophiomorpha irregulaire Frey, Howard \& Pryor, 1978

(Figs 3b, 4-6) 

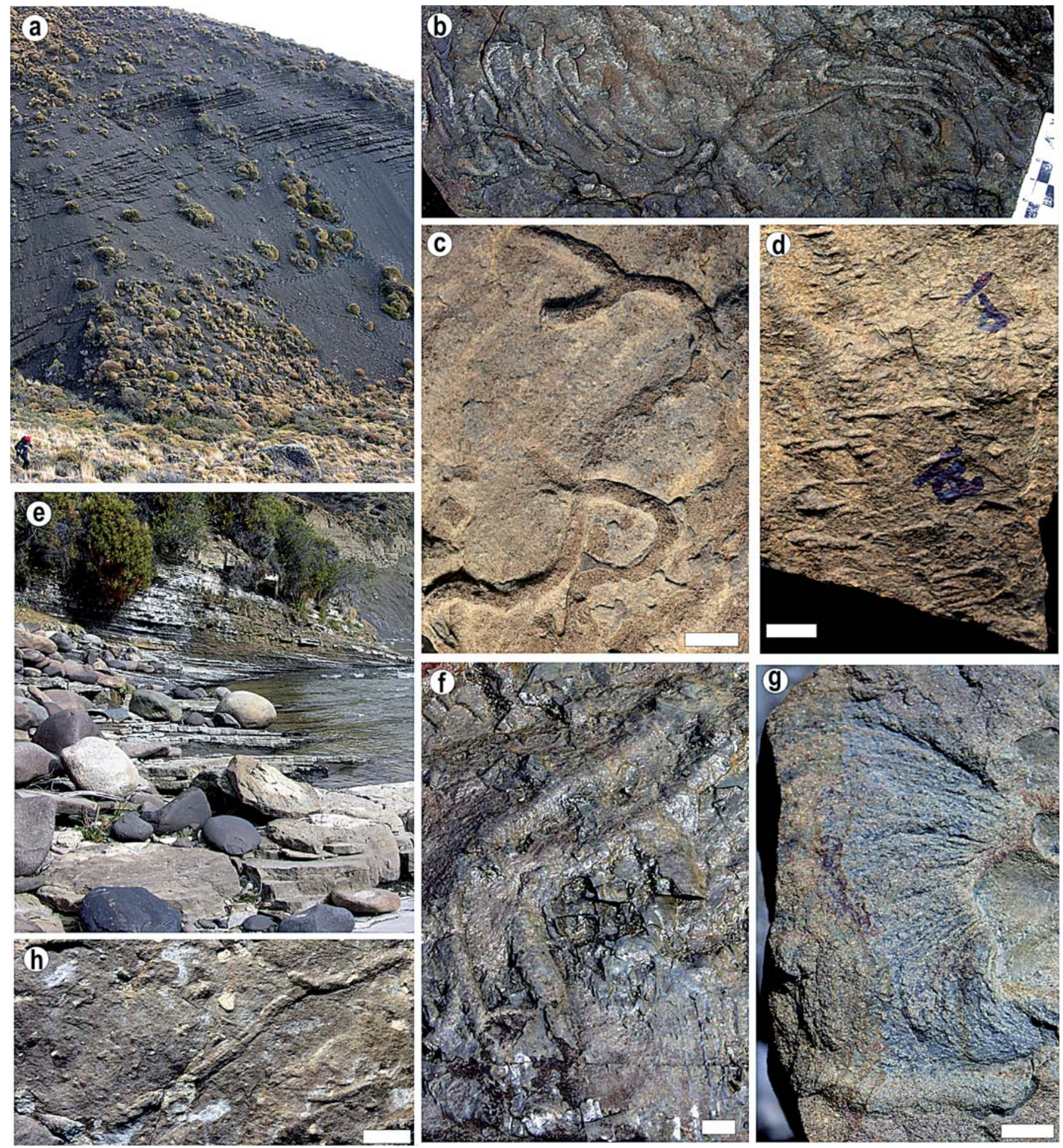

Figure 2. Sedimentary facies and trace fossils from the studied localities. a-d, f): Cerro Frías; (a) thin-bedded turbidites of the Cerro Toro Formation; (b) Helminthorhaphe flexuosa Uchman, field specimen; (c) Megagrapton submontanum (Azpeitia-Moros), specimen CADIC PI 308; (d) Desmograpton ichthyforme (Macsotay), specimen CADIC PI 307; (f) Scolicia strozzi (Savi \& Meneghini), field specimen. b-d, f) Positive hyporelief at the sole of Tc-e turbidites. e, g-h) Arroyo Centinela; (e) classical turbidites of the Alta Vista Formation; (g) Zoophycos isp., full relief, field specimen; (h) Halopoa annulata (Książkiewicz), positive hyporelief, specimen CADIC PI 306. Scale bar: $1 \mathrm{~cm}$. 
Emended diagnosis. Predominantly horizontal Ophiomorpha system characterized by branched meander maze galleries of variable geometries, T- or Y-shaped at point of bifurcation. Wall lining consists of irregularly distributed pellets, mostly concentrated on the roof and composed of a sand core encased in a muddy lining. After compaction the lining usually results in distinctive spiky projections. The floor of the galleries is commonly unlined.
Remarks on diagnosis. In a first diagnosis, the ichnospecies was defined as "Burrows wall consisting predominantly of sparse, irregularly distributed, ovoid to mastoid pellets or pelletal masses" (Frey et al., 1978). This diagnosis stressed on the irregularly distribute pelletal masses of the burrow walls; a character from which the ichnospecific name was derived. They also interpreted the "flame structures" of the pelletal masses as resulting from soft sediment deformation of the muddy lining.
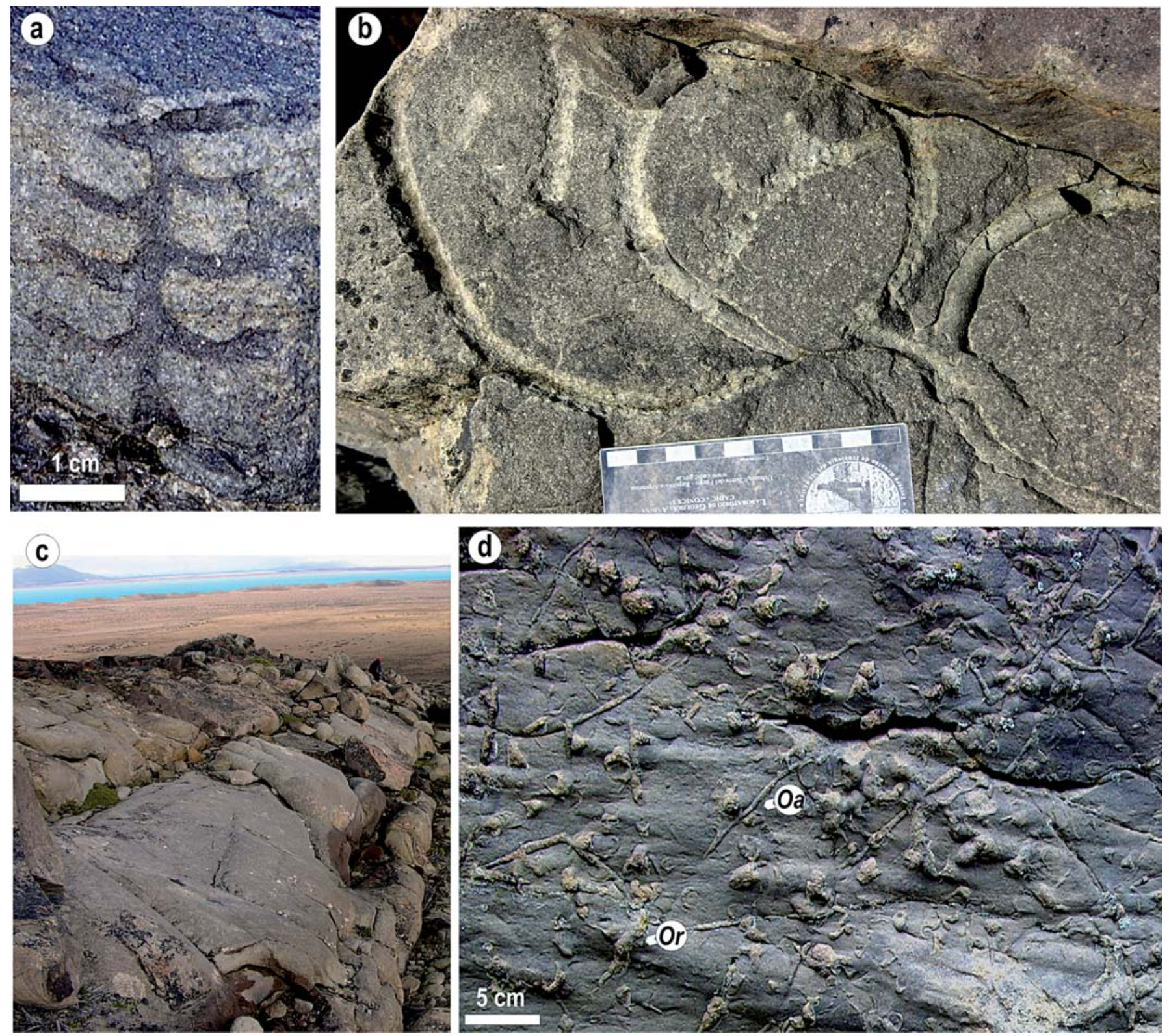

Figure 3. Sedimentary facies and trace fossils from the studied localities. a-b) Arroyo Centinela; (a) Spirophyton isp., full relief, specimen CADIC PI 309; (b) Ophiomorpha irregulaire Frey, Howard \& Pryor, full relief, field specimen forming a horizontal maze in the middle of a loose sandstone block, the base of the bed is facing upward, note the knobby appearance of the pelletal impressions. c-d) Arroyo Horqueta; (c) thick-bedded lenticular sandstones of the Alta Vista Formation; (d) Ophiomorpha annulata (Książkiewicz) and O. rudis (Książkiewicz), indicated as $\mathrm{Oa}$ and Or, respectively, at the sole of a thick-bedded turbidite, field specimens. 
A second, emended diagnosis was defined by Bromley \& Ekdale (1998) as "Predominantly horizontal Ophiomorpha system having T-and/or Y-shaped branch nodes; geometry of the systems is a meander maze having smoothly curved internodal tunnels; cross section is oval; roof lining is pelleted with regularly or irregularly spaced, conical to attenuated, outwardly tapering pellets of non-uniform size; interior surface of this lining is smooth; floor commonly unlined, locally bearing longitudinal grooves". The emended diagnosis incorporated features regarding the size and forms of the pellets and include the morphology of the maze as important ichnotaxobase at ichnospecific level.

Recently, Boyd et al. (2012) established that the mud-lined pellets of $O$. irregulaire have a sand core and considered that the distinctively spiky outer surface to the burrow wall results from compaction after burial of the clay coating. Even though these flame-like projections would be a secondary character resulting from compression during burial, Boyd et al. (2012) concluded that these spiky projections derive from a primary morphological feature of the burrow wall, and thus they are considered of taxonomic importance.

Based on the above considerations, our emended diagnosis of $O$. irregulaire incorporates the most characteristic and distinctive features already defined from the type material (Frey et al., 1978; Bromley \& Ekdale, 1998; Boyd et al., 2012), most of which are present also in the newly described material from Lago Argentino.

Description. The trace fossil is characterized by horizontal, branched meander maze galleries with segments in the form of open $U$ and circular loops. The maze can develop a large size, usually reaching more than $1 \mathrm{~m}$ in length (Figs 3b, 4a-b).

Galleries consist of oval to circular tubes in cross-section, $0.86-1.2 \mathrm{~cm}$ in diameter. At point of branching segments of circular loops forms Y-shaped, rather than T-shaped bifurcations; enlargement of the gallery is not observed at the branching point. The wall of the galleries presents the characteristic flame-like projections of $O$. irregulaire, resulting from the deformation of the thin, dark mud lining of the wall (Figs 4c-d, 5a, 8b). When fully preserved, the pellets have a sandy core, circular to oval in section, which is enclosed in a darker muddy lining (Figs 4, 5a). Pelletal masses appear unevenly distributed, mostly on the roof of the burrows. In weathered surfaces, the outer impression of the pelleted wall has a knobby appearance (Fig. 3b). Internal filling of the galleries occasionally presents a chevron-like backfill; minute plant detritus in evident less proportion than in the host-sediment are distributed sporadically in the fill and wall of the galleries (Figs 4d, 5a). Overcrossing (Fig. 5d) and crosscutting (Fig. 5c) are common. Vertical shafts are rare; only two cases with vertical to rather oblique shaft have been observed (Fig. 5e). The trace is mostly preserved in full relief.
Remarks. Even though in outcrop examples the mazes commonly share a general meander pattern, differences can be noted, including: a) gallery segments with strong sinuous course, dominated by $\mathrm{S}$ and $\mathrm{U}$ shapes, as in the type material (Ekdale \& Bromley, 1998); b) galleries with lesser branching points that have segments with loop patterns following a semicircle, as in the material from the Atane Formation (Pedersen \& Bromley, 2006); and c) galleries with less meandering circular loops or open Ushaped segments as in the specimens from the Alta Vista Formation (Figs 4a-b).

Interestingly, the distinctive circular loops of the studied specimens are also well developed in the material of the Star Point Formation as shown in Figure $6 \mathrm{~b}$ and in Frey et al. (1978, figure 12a, p. 219). Intergradations of morphologies in a single specimen suggest that these differences have no ichnotaxonomic value.

At the type locality in Utah, galleries of $O$. irregulaire are $3-5 \mathrm{~cm}$ wide, similar to the width $(2.5-4.5 \mathrm{~cm})$ of the specimens of the Atane Formation. In the studied material from Lago Argentino, the diameter of the galleries ranges from 0.86 to $1.2 \mathrm{~cm}$, a size consistently smaller than that of the galleries in the material from Utah or West Greenland.

\section{DISCUSSION}

\subsection{Palaeoenvironmental and palaeogeographical distribution}

At the type area of the Book Cliffs, central Utah (Frey et al., 1978; Bromley \& Ekdale, 1998), O. irregulaire occurs in the Late Cretaceous, shallow marine Star Point and Blackhawk formations. In the Blackhawk Formation, the trace fossil is relatively abundant in fully bioturbate, fine-grained sandstones of the middle shoreface or in poorly sorted muddy fine- to medium-grained sandstones containing organic matter of the lower shoreface (Howard \& Frey, 1984). In the Star Point Formation O. irregulaire occurs in fine to medium-grained sandstones, interpreted as mouth bar deposits of a prograding deltaic system (Gibert \& Benner, 2002). In the Atane Formation, Late Cretaceous, West Greenland, O. irregulaire occurs in medium-grained sandstones interpreted as representing transgressive shoreface and delta front deposits (Pedersen \& Bromley, 2006).

At Lago Argentino, O. irregulaire occurs also in fine-grained sandstone beds, generally enriched in carbonized plant material. But in this case the interpreted environmental settings, sedimentation processes, and trace fossil assemblage are, quite different from those 

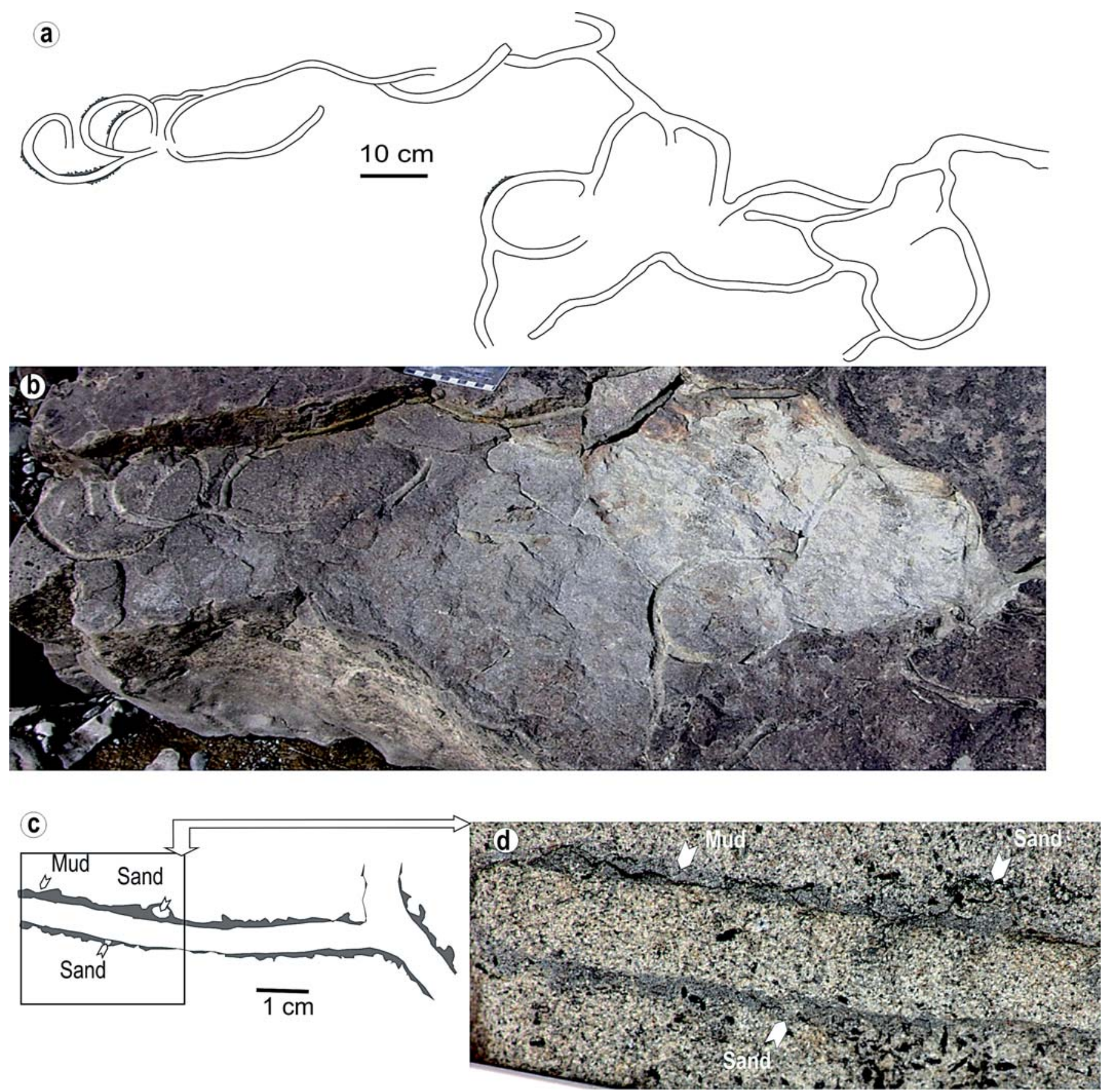

Figure 4. Ophiomorpha irregulaire from the Alta Vista Formation at Arroyo Centinela. a-b) line drawing (a) and corresponding field photograph (b) of a large meander maze of $O$. irregulaire, full relief, field specimen forming a horizontal maze in the middle of a loose sandstone bed, the base of which is facing upward. c-d) line drawing showing details of the dark mud lining and sand-cored pellets, based on the specimen CADIC-PI 303 of Figure 5a, horizontal view, square indicate position of enlarged picture shown in $\mathrm{d}$.

recognized in the Book Cliffs. Although in the Alta Vista Formation the sandstones beds are genetically related to deltaic systems, they are turbidites deposited from gravity flows originating in a delta front (Arbe \& Hechem, 1984; Macellari et al., 1989).

In the outcrop belt of the Tres Pasos Formation in southern Chile, we have also found isolated specimens of
O. irregulaire (Fig. 6a) in loose sandstone slabs used as building material at Estancia Guido. According to the farm owner the provenance of these sandstone slabs is from a nearby quarry, located within the outcrop belt of the Tres Pasos Formation. These sandstones are interpreted as gravity flow deposits emplaced in an upper slope setting (Hubbard et al., 2010). 

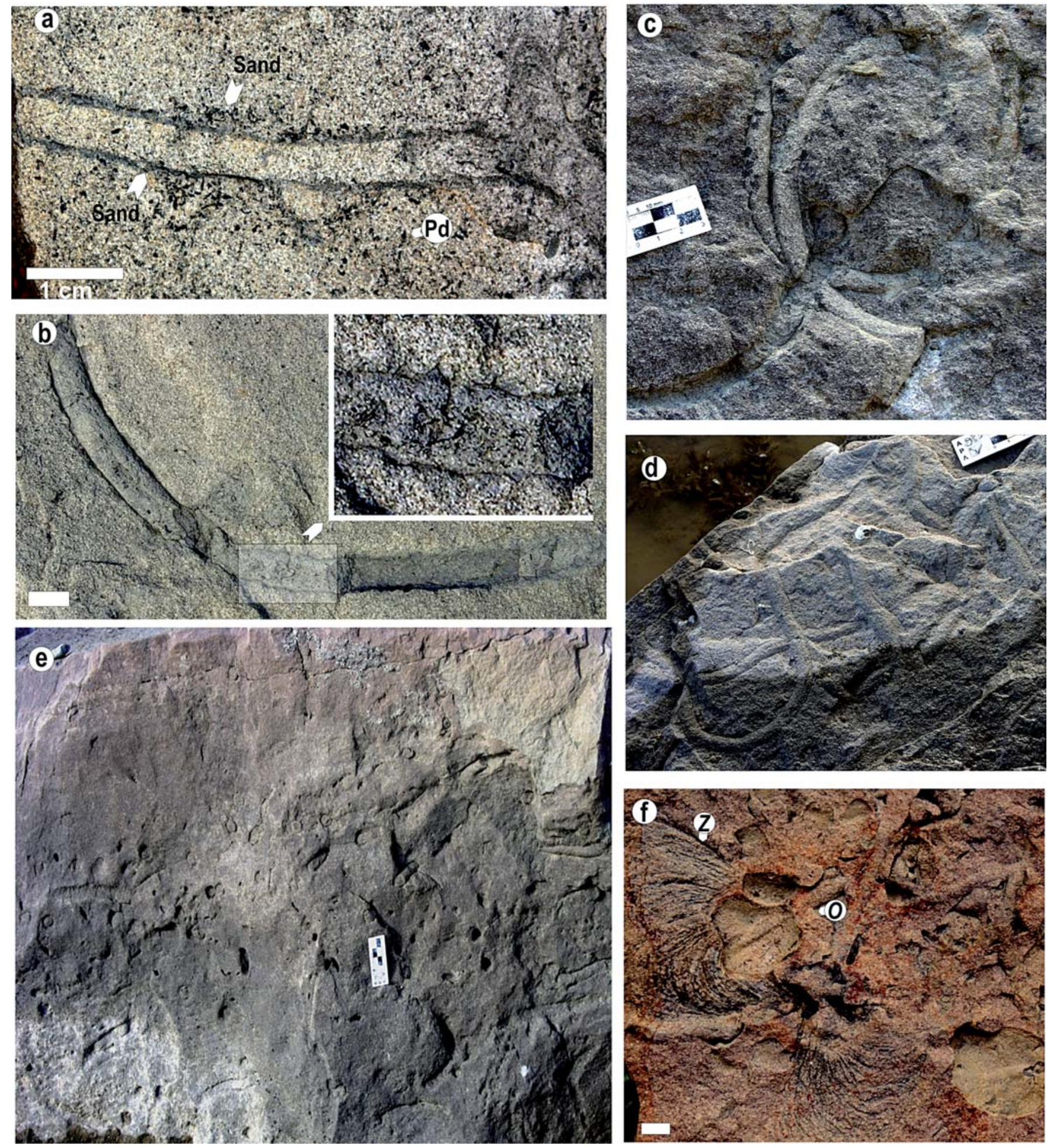

Figure 5. Ophiomorpha irregulaire from the Alta Vista Formation at Arroyo Centinela; a) specimen CADIC PI 303 in fine-grained sandstone with abundant plant detritus (Pd) showing details of the mud lining and sand-cored pellets, note that the material filling the galleries contains less plant detritus than the host sediment. b) Field specimen showing details of pelletal morphology, square indicate position of close-up. c) Field specimens showing crosscutting galleries. d) Field specimens showing overcrossing galleries. e) Thick sandstone bed in vertical view with occurrence at several levels of horizontal galleries and some vertical to oblique shafts of $O$. irregulaire, field specimens. f) Hyporelief, showing galleries of $O$. irregulaire $(\mathrm{O})$ crosscutting Zoophycos $(Z)$, field specimens. (a-d) full relief, horizontal view. Scale bar: $1 \mathrm{~cm}$. 
The diameter of the galleries in O. irregulaire from the Alta Vista turbidites is consistently smaller than that of the Western Interior material recorded in deltaic to shoreface deposits (see Systematic Ichnology, Description). These differences in the diameter of the galleries may be explained by the miniaturization of the gallery system of crustacean burrows at deeper settings, where the producers were able to penetrate thick sedimentary layers in search for nutrientrich beds along the turbidite soles (Seilacher, 2007).

The record of $O$. irregulaire was considered to be endemic of the Western Interior Seaway and restricted to the Cretaceous (Bromley \& Pedersen, 2008). Indeed, the trace fossil is best known in the Cretaceous of the Western Interior, but specimens of $O$. irregulaire in outcrops have been mentioned also in the Jurassic (Monaco \& Garrasino, 2001; McIlroy, 2007; Patel et al., 2012). Occurrences in well cores also suggest that $O$. irregulaire is distributed in post-Palaeozoic shallow marine deposits (Boyd et al., 2012, and the bibliography therein).

\subsection{Ethology}

The record of $O$. irregulaire in the turbidites of the Alta Vista and Tres Pasos formations indicates that this trace fossil is not exclusive of shallow marine, shoreface and delta mouth bar deposits. In either setting the trace fossil seems to be characteristic of fine-grained sandstones containing abundant plant detritus, which suggests a possible causal relationship. O. irregulaire was originally considered a fodinichnion (Howard \& Frey, 1984) or a trace produced by a suspension feeding organism (Pedersen \& Bromley, 2006). A conspicuous feature of our $O$. irregulaire specimens is the strong contrast in the amount of plant detritus present in the host rock and within the galleries. Whereas the fill material inside the galleries is the same than that of the host rock, the amount of carbonized plant detritus in the filling is consistently much lower than that of the host rock (Figs 4d, 5a). The deep-marine trace fossil Ophiomorpha rudis commonly occurs also in turbidites containing abundant plant detritus. Its producer probably fed on this organic matter, previously decomposed by bacteria or used the plant material for bacterial cultivation as a food resource (Uchman, 2009). A similar behaviour may be inferred for the producer of $O$. irregulaire, but possible in this case it was a detritus feeding organism that fed directly on previously decomposed plant detritus.

In the Book Cliffs and West Greenland, O. irregulaire is associated with Cylindrichnus, Schaubcylindrichnus, Teichichnus and Chondrites. Mutual crosscuttings and the inferred tier relationships point to a shallow colonization
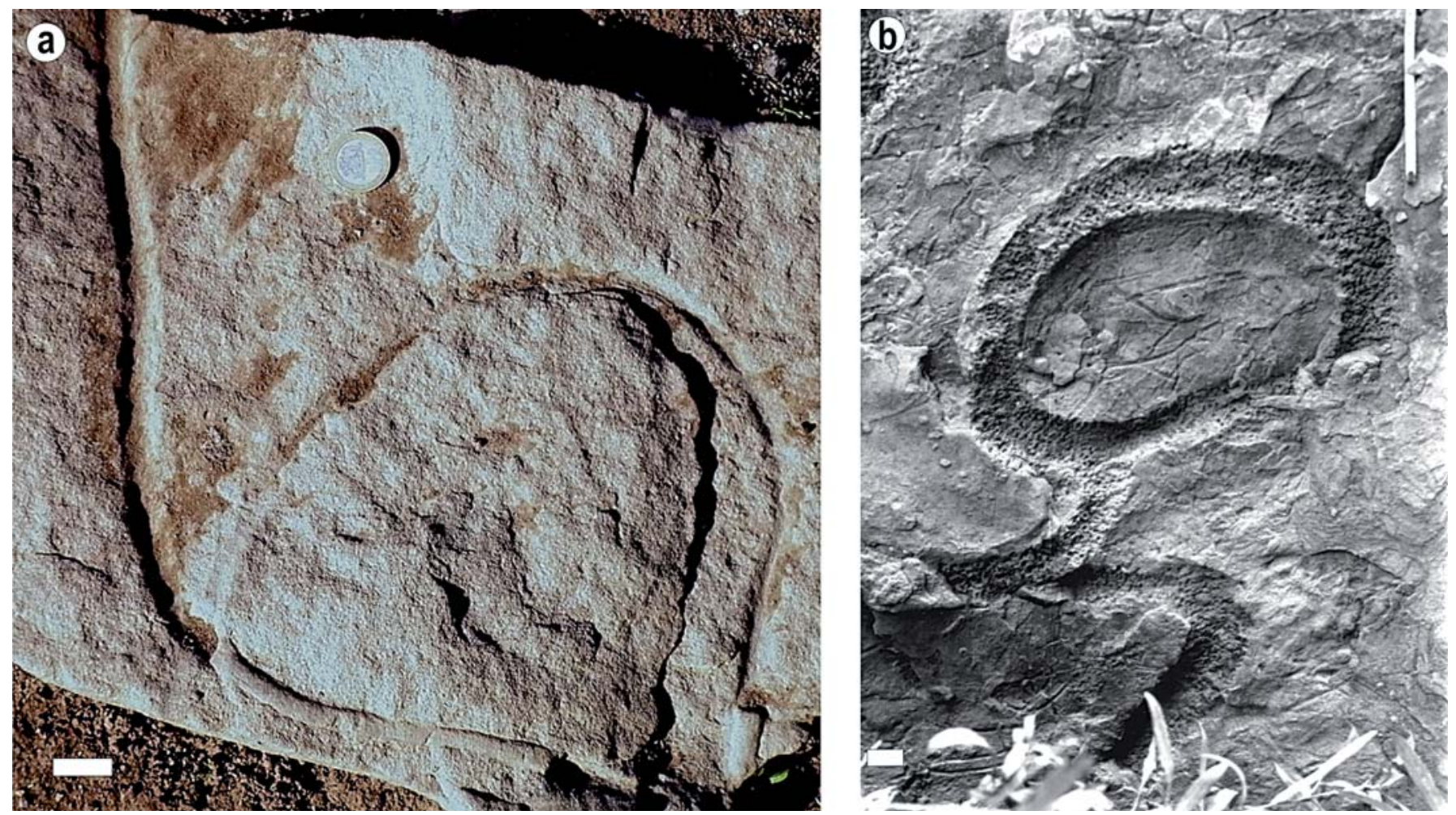

Figure 6. Field specimens of Ophiomorpha irregulaire from the Tres Pasos Formation, Estancia Guido, Chile (a), and the Star Point Formation, central Utah, USA (b, courtesy of J. M. de Gibert). Lower bedding plane view. Scale bar: $2 \mathrm{~cm}$. 
by the producer of $O$. irregulaire (Bromley \& Ekdale, 1998; Gibert \& Bennet, 2002; Pedersen \& Bromley, 2006).

In the Alta Vista Formation, the meandering maze of $O$. irregulaire at the Arroyo Centinela locality has two types of occurrences: in thick-bedded channelized sandstones, sporadically associated with small Zoophycos isp. (Figs 2g, 5f) or in classical turbidites, associated with Spirophyton isp. and Halopoa annulata (Książkiewicz, 1977) (Figs 2h, 3a; see also Olivero \& López Cabrera, 2012). In the thick-bedded sandstones $O$. irregulaire crosscuts Zoophycos (Fig. 5f), suggesting a rather deeper emplacement for the producer than that of the shallower burrows in the Book Cliffs and West Greenland. A similar deeper emplacement for the producer of $O$. irregulaire is suggested by the occurrences at the Alta Vista Formation of meander mazes at different levels within a single thickbedded sandy turbidite, without obvious evidence of amalgamation (Fig. 5e).

\section{CONCLUSIONS}

The study of well-preserved mazes of Ophiomorpha irregulaire and associated trace fossils from the Upper Cretaceous turbidites of the Alta Vista Formation, Lago Argentino, Southern Patagonia, confirms the characteristic morphology and composition of the pelletal masses of the ichnospecies and provides new evidence on the palaeogeographical and palaeoenvironmental distribution and ethology of the producer of $O$. irregulaire.

1) As in the type material from the Book Cliffs (Boyd et al., 2012), the studied specimens partially preserve pellets composed of a sandy core surrounded by a lining of dark mud. Similarly, the flame-like spiky projections to the outer wall of $O$. irregulaire seem to result from compaction and partial lost after burial of the outermost mud lining on top of the sandy core of the pellets.

2) The record of $O$. irregulaire in southern Patagonia, Argentina, indicates that the ichnospecies is not endemic of the Western Interior. In southern Patagonia $O$. irregulaire is found in classical and thick-bedded turbidites deposited in a slope system from gravity flows that probably originated in delta front settings. This new finding indicates that the trace fossil is not exclusive of tidal, shoreface, and delta mouth bar deposits.

3 ) In comparison with the type material from the Western Interior the diameter of the galleries in $O$. irregulaire from the Alta Vista turbidites is consistently smaller. These differences may reflect the known trend of miniaturization of the gallery system of crustacean burrows in deeper settings.

4) O. irregulaire from the Alta Vista Formation is associated with distinctive fodinichnia, including Halopoa,
Spirophyton, and Zoophycos. In addition, the trace fossil is commonly found in fine-grained sandstones with abundant plant detritus, but the material filling the galleries contains less plant detritus than the host sediments, suggesting that the producer may have fed on previously decomposed plant material. Based on the latter fact and on its association with typical fodinichnia, it is concluded that the producer of $O$. irregulaire was possible a deposit feeder.

5) Crosscutting relationships with Zoophycos and the occurrence at several levels of $O$. irregulaire within a single, thick bedded sandstone turbidite, probably indicates a deeper tier than that of the specimens from the Book Cliff and West Greenland.

\section{ACKNOWLEDGMENTS}

We dedicate this study to the memory of Jordi de Gibert who initially advised us about $O$. irregulaire in occasion of the ICHNIA 2008 Meeting held in Cracow, Poland. Later on, he kindly sent us a picture of $O$. irregulaire from the Start Point Formation, Book Cliffs, Utah, showing the same gross morphological features of the Lago Argentino material, which we reproduced in this paper, encouraging us to publish our finding. We thank the guest editors A.A. Ekdale, J. Martinell, R. Domènech and J.A. Gámez Vintaned for the initiative of preparing this special volume in honour of Jordi M. de Gibert. Comments by the guest editor (A.A. Ekdale) and reviewers (F.M.W. Tognoli and J.K. Lindqvist) help to improve the original manuscript. L. Buatois helped with bibliography. Part of this study was financed by PIP CONICET 114 and PICTO ANPCyTDNA 0114, Argentina.

\section{REFERENCES}

Arbe, H.A. \& Hechem, J.J. 1984. Estratigrafía y facies de depósitos marinos profundos del Cretácico Superior, Lago Argentino, Provincia de Santa Cruz. Noveno Congreso Geológico Argentino, Actas 5, 7-41.

Azpeitia-Moros, F. 1933. Datos para el estudio paleontológico de la costa Cantábrica y de algunos otros puntos de España. Boletín del Instituto Geológico y Minero de España, 53, 1-65.

Boyd, C., McIlroy, D., Herringshaw, L.G. \& Leaman, M. 2012. The recognition of Ophiomorpha irregulaire on the basis of pellet morphology: restudy of material from the type locality. Ichnos, 19, 185-189.

Bromley, R.G. \& Ekdale, A.A. 1998. Ophiomorpha irregulaire (trace fossil): redescription from the Cretaceous of the Book Cliffs and Wasatch Plateau, Utah. Journal of Paleontology, 72, 773-778. 
Bromley, R.G. \& Pedersen, G.K. 2008. Ophiomorpha irregulaire, Mesozoic trace fossil that is either well understood but rare in outcrop or poorly understood but common in core. Palaeogeography, Palaeoclimatology, Palaeoecology, 270, 295-298.

Feruglio, E. 1949. Descripción Geológica de la Patagonia. Dirección General de Yacimientos Petrolíferos Fiscales, Buenos Aires, 3 Volúmenes.

Frey, R.W., Howard, J.D. \& Pryor, W.A. 1978. Ophiomorpha: Its morphologic, taxonomic, and environmental significance. Palaeogeography, Palaeoclimatology, Palaeoecology, 23, 199-229.

Furque, G. 1963. Descripción geológica de la Hoja 58B, Lago Argentino, Provincia de Santa Cruz. Boletín del Servicio Nacional Minero Geológico, 140, 1-51.

Gibert, J.M. de \& Benner, J.S. 2002. The trace fossil Gyrochorte: ethology and paleoecology. Revista Española de Paleontología, 17, 1-12.

Heinzelin, J. de, 1964. Pogonophores fossils?. Bulletin Société Belge de Géologie, Paléontologie et d'Hydrogéologie, 73, 501-510.

Howard, J.D. \& Frey, R.W. 1984. Characteristic trace fossils in nearshore to offshore sequences, Upper Cretaceous of east-central Utah. Canadian Journal of Earth Sciences, 21, 200-219.

Hubbard, S.M., Romans, B.W. \& Graham, S.A. 2008. Deepwater foreland basin deposits of the Cerro Toro Formation, Magallanes Basin, Chile: architectural elements of a sinuous axial channel belt. Sedimentology, 55, 1333-1359.

Hubbard, S.M., Fildani, A., Romans, B.W., Covault, J.A. \& McHargue, T. 2010. High relief slope clinoform development: insights from outcrop, Magallanes Basin, Chile. Journal of Sedimentary Research, 80, 357-375.

Katz, H.R. 1963. Revision of Cretaceous stratigraphy in Patagonian Cordillera of Ultima Esperanza, Magallanes Province, Chile. American Association of Petroleum Geologists Bulletin, 47, 506-524.

Książkiewicz, M. 1977. Trace fossils in the Flysch of the Polish Carpatians. Palaeontologica Polonica, 36, 1-208.

Lundgren, S.A.B. 1891. Studier öfer fossilförande lösa block. Geologiska Föreningens i Stockholm Förhandlingar, 13, 111-121.

Macellari, C.E., Barrio, C.A. \& Manassero, M.J. 1989. Upper Cretaceous to Paleocene depositional sequences and sandstone petrography of southwestern Patagonia (Argentina and Chile). Journal of South American Earth Sciences, 2, 223-239.

McIlroy, D. 2007. Ichnology of a macrotidal tide-dominated deltaic depositional systems: Lajas Formation, Neuquén Province, Argentina. In: Sediment-Organism Interactions: a Multifaceted Ichnology (eds Bromley, R.G., Buatois, L.A., Mángano, M.G., Genise, J.F. \& Melchor R.). SEPM Special Publication, 88, 195-212.
McIlroy, D., Tonkin, N.S., Phillips, C. \& Herringshaw, L.G. 2009. Comment on "Ophiomorpha irregulaire, Mesozoic trace fossil that is either well understood but rare in outcrop or poorly understood but common in core" by R.G. Bromley \& G.K. Pedersen. [Palaeogeography, Palaeoclimatology, Palaeoecology 270 (2008) 295-298]. Palaeogeography, Palaeoclimatology, Palaeoecology, 284, 392-395.

Macsotay, O. 1967. Huellas problemáticas y su valor paleoecológico en Venezuela. Géos, 16, 7.

Monaco, P. \& Garassino, A. 2001. Burrows and body fossil of decapod crustaceans in the Calcari Grigi, Lower Jurassic, Trento Platform (Italy). Geobios, 34, 291-301.

Olivero, E.B. \& López Cabrera, M.I. 2010. Tasselia ordamensis: A biogenic structure of probable deposit-feeding and gardening maldanid polychaetes. Palaeogeography, Palaeoclimatology, Palaeoecology, 292, 336-348.

Olivero, E.B. \& López Cabrera, M.I. 2012. Trazas fósiles de ambientes marinos profundos del Cretácico Superior del Lago Argentino, Santa Cruz, Argentina (Deep marine trace fossils from the Upper Cretaceous of Lago Argentino, Santa Cruz, Argentina). Tercer Simposio-Paleontología en Chile, Libro de Resúmenes, 127-130.

Patel, S.J., Nenuji, V. \& Joseph, J.K. 2012. Trace fossils from the Jurassic rocks of Gangta Bet, Eastern Kachchh, Western India. Journal of the Palaentological Society of India, 57, 59-73.

Pedersen, G.K. \& Bromley, R.G. 2006. Ophiomorpha irregulaire, rare trace fossil in shallow marine sandstones, Cretaceous Atane Formation, West Greenland. Cretaceous Research, 27, 964-972.

Riccardi, A.C. 1983. Kossmaticeratidae (Ammonitina) y nomenclatura estratigráfica del Cretácico tardío en Lago Argentino, Santa Cruz, Argentina. Ameghiniana, 20, 317- 345 .

Savi, P. \& Meneghini, G.G. 1850. Observazioni stratigrafische e paleontologische concernati la geologia della Toscana e dei paessi limitrofi. Appendix. In: Memoria sulla struttura geologica delle Alpi, degli Apennini e dei Carpazi, 246528, Firenze.

Seilacher A. 2007. Trace Fossil Analysis. Springer-Verlag, Berlin.

Uchman, A. 1995. Taxonomy and paleoecology of flysch trace fossils: The Marnoso arenacea Formation and associated facies (Miocene, Northern Apennines, Italy). Beringeria, $15,1-115$.

Uchman, A. 2009. The Ophiomorpha rudis ichnosubfacies of the Nereites ichnofacies: characteristics and constraints. Palaeogeography, Palaeoclimatology, Palaeoecology, 276, 107-119.

Winn, R.D. \& Dott, R.H. 1979. Deep-water fan-channel conglomerates of Late Cretaceous age, southern Chile. Sedimentology, 26, 203-228. 
